\title{
Coexpression of EGFR and HER-2 in pancreatic ductal adenocarcinoma: A comparative study using immunohistochemistry correlated with gene amplification by fluorescencent in situ hybridization
}

\author{
JANE DANCER $^{1}$, HIDEHIRO TAKEI $^{1}$, JAE Y. RO $^{1}$ and MARY LOWERY-NORDBERG ${ }^{2}$ \\ ${ }^{1}$ Department of Pathology, Weill Medical College of Cornell University, The Methodist Hospital, Houston, TX; \\ ${ }^{2}$ Department of Molecular Pathology, Feist-Weiller Cancer Center, Shreveport, LA, USA
}

Received March 13, 2007; Accepted April 23, 2007

\begin{abstract}
Pancreatic ductal adenocarcinoma (PDAC) is the major pancreatic tumor and carries an extremely poor prognosis. Coexpression of epidermal growth factor receptor (EGFR) and the HER-2 oncoprotein has been reported to be related to the invasion and an adverse clinical outcome of human pancreatic ductal adenocarcinomas. HER-2 amplification, as determined by fluorescent in situ hybridization (FISH) analysis, has been identified as a positive predictor of response to EGFR tyrosine kinase inhibitor treatment in some other cancers. The aim of this study was to investigate the coexpression rate and amplification status of HER-2 oncogene in EGFR positive pancreatic ductal adenocarcinoma (PDAC) by immunohistochemistry and FISH. Overexpression of EGFR $\left(\geq 2^{+}\right)$was seen in $65 \%$ (21/32) of the study cases. EGFR gene amplification was not detected in any of the 32 PDACs. Overexpression of HER-2 protein $\left(\geq 2^{+}\right)$was seen in $17 \%(5 / 28)$ of the study cases and in $24 \%$ $(5 / 21)$ of EGFR positive cases. None of the EGFR negative tumors showed HER-2 overexpression or gene amplification. The HER-2 gene locus was amplified in $11 \%(3 / 28)$ of the study cases and in $14 \%$ (3/21) of EGFR positive PDACs. There was $60 \%$ concurrence between HER-2 gene amplification and HER-2 protein expression in this study. These results suggest that HER-2 is an important cooperating member of the EGFR signal pathway in a subset of PDAC.
\end{abstract}

\section{Introduction}

Pancreatic ductal adenocarcinoma (PDAC) accounts for $2 \%$ of malignant tumors in both men and women, but was the

Correspondence to: Dr Jane Dancer, Department of Pathology, M227, The Methodist Hospital, 6565 Fannin St., Houston, TX 77030, USA

yzdancer@tmh.tmc.edu

Key words: epidermal growth factor receptor, HER-2, pancreatic ductal adenocarcinoma fourth leading cause of cancer deaths after lung, colon and prostate for men, and lung, breast, and colon for women in the US in 2006 (1). Since most patients with PDAC present late in the course of their disease, and are detected in the late stages of the disease, their mortality rates are extremely high, and most patients die of the disease within a year (2).

Both epidermal growth factor receptor (EGFR) and HER-2 oncoprotein are members of the human EGFR family of transmembrane receptor tyrosine kinases and have crucial roles in the growth, repair, and differentiation of cells. In a normal pancreas, EGFR is rarely expressed only in the Langerhans islands and ductal cells, whereas EGFR overexpression has been reported to occur in $>15-60 \%$ of both surgically resected pancreatic carcinoma and pancreatic carcinoma cell lines (3). The overexpression of EGFR has been shown to enhance the production of EGF and TGF- $\alpha$ by promoting autocrine and paracrine loops and cell proliferation.

EGFR inhibitors, including the monoclonal antibodies directing the receptors and the small molecule tyrosine kinase inhibitors (TKIs) have been implicated and demonstrated to have some effects in non-small cell lung cancers (NSCLCs) (4). The association with EGFR mutations, and sensitivity to the EGFR inhibitors in the NSCLC, have been described in retrospective studies $(5,6)$. The associations with EGFR expression and EGFR copy numbers have also been reported. It has become increasingly clear that EGFR works in concurrence with other EGFR family members, especially HER-2 and ErbB3 in the NSCLCs (7). HER-2 has been identified as a potentially important component of the EGFR signaling network and particularly in the EGFR TKI-sensitive NSCLCs (8). HER-2 amplification, as determined by fluorescent in situ hybridization (FISH) analysis, was identified as a positive predictor of response to EGFR TKI treatment.

HER-2 overexpression has also been reported to be correlated with glandular differentiation and early oncogenesis in pancreatic cancer (9). Coexpression of EGFR and the HER-2 oncoprotein has been reported to be related to the invasion and an adverse clinical outcome in pancreatic adenocarcinomas. In this study, we performed 
immunohistochemical and FISH analyses of EGFR and HER-2 to determine the coexpression and amplification of EGFR and HER-2 in PDAC.

\section{Materials and methods}

Patients and tumor specimens. Representative tissue samples from 32 cases of nonselected PDAC were obtained from the surgical pathology PDAC patient database that underwent resection at Louisiana State University Health Science Center (LSUHSC) and from consultation files between January 1997 and March 2005. Hematoxylin-eosin stains were reviewed by two pathologists, and representative paraffin-embedded blocks were selected for further analysis. Clinicopathological characteristics of the 32 patients were evaluated including age, tumor size, and AJCC stage. There were 20 female and 12 male patients. The median age of the patients at the time of operation was 64 (range: 34-82) years.

Immunohistochemical stain. EGFR and HER-2 expressions were evaluated with an immunohistochemical technique on $5-\mu \mathrm{m}$ tissue sections obtained from paraffin-embedded specimens fixed in $10 \%$ neutral-buffered formalin. Immunohistochemical staining for HER-2 was performed in 28 cases with the HercepTest kit (Dako, Carpinteria, CA). Immunohistochemical staining for EGFR was performed in 32 cases using the EGFR pharm Dx kit (Dako). Positive staining for EGFR and HER-2 were evaluated by both manual microscopic evaluation and automated cellular image system (ACIS) (Chromavision Inc., CA, USA) to validate the manual analysis. Manual microscopic scoring was evaluated according to the manufacturer's instructions using the following scale: 0 and $1^{+}$, normal HER-2 /EGFR expression and 2 and $3^{+}$, HER-2/ EGFR overexpression. The high color staining covered at least $10 \%$ of the specimen for a positive evaluation of overexpression. For ACIS evaluation in each slide, a minimum of 6 areas were chosen in which the intensity of color was evaluated and then quantified to give HER-2 and EGFR expression scores that were dependent on median staining intensity of the 6 areas.

Fluorescent in situ hybridization (FISH). The PathVysion kit (Vysis, Downers Grove, IL) was used for FISH studies. FISH for HER-2 was performed in 28 cases with dual color HER-2 Spectrum Orange/CEP17 spectrum green-labeled probe. FISH for EGFR was performed in 32 cases with the dual color EGFR Spectrum Orange/CEP7 spectrum green-labeled probe. The CEP rapid assay protocol (Vysis) was used. Slides containing $3-\mu \mathrm{m}$ sections of the tumor were dehydrated by serial treatment with increasing concentrations of ethanol. Prior to hybridization, the slides were treated with the Paraffin pretreatment reagent kit (Vysis). DNA denaturation was carried out at $75^{\circ} \mathrm{C}$ for $10 \mathrm{~min}$ (probe mixture) or $5 \mathrm{~min}$ (slides). For interpretations of EGFR, CEP7 (chromosome 7, green signal) and EGFR (red signal) were counted in a minimum of 30 cells using a fluorescence microscope. For interpretations of HER-2, CEP17 (chromosome 17, green signal) and HER-2 (red signals) were counted using a fluorescence microscope in a minimum of 30 cells. A ratio of red to green signals of 2.0 or $>2.0$ was interpreted as cases with
Table I. Summary data of pancreatic ductal adenocarcinoma cases.

\begin{tabular}{|c|c|c|c|c|c|}
\hline $\begin{array}{l}\text { Case } \\
\text { No. }\end{array}$ & $\begin{array}{c}\text { Age } \\
(\mathrm{yr}) / \mathrm{sex}\end{array}$ & Stage & IHC-HER2 & $\begin{array}{c}\text { HER-2 } \\
\text { Gene Ratio }\end{array}$ & $\begin{array}{l}\text { IHC- } \\
\text { EGFR }\end{array}$ \\
\hline 1 & $75 / \mathrm{F}$ & I & 1 & 1.1 & 3 \\
\hline 2 & $50 / \mathrm{F}$ & I & 1 & 1.0 & 2 \\
\hline 3 & $82 / \mathrm{F}$ & I & 1 & 1.0 & 1 \\
\hline 4 & $54 / \mathrm{F}$ & $\mathrm{I}$ & 2 & 1.2 & 1 \\
\hline 5 & $34 / \mathrm{F}$ & I & 1 & 1.19 & 1 \\
\hline 6 & $77 / \mathrm{F}$ & I & - & - & 1 \\
\hline 7 & $59 / \mathrm{F}$ & I & 1 & 1.02 & 3 \\
\hline 8 & $76 / \mathrm{F}$ & I & 1 & 1.05 & 2 \\
\hline 9 & $62 / \mathrm{F}$ & $\mathrm{I}$ & 2 & 2.02 & 1 \\
\hline 10 & $64 / F$ & II & 1 & 1.07 & 2 \\
\hline 11 & 64/M & II & 3 & 2.3 & 3 \\
\hline 12 & $58 / \mathrm{M}$ & II & 1 & 1.0 & 2 \\
\hline 13 & $60 / \mathrm{M}$ & II & 1 & 1.12 & 1 \\
\hline 14 & $80 / \mathrm{F}$ & II & 3 & 6.3 & 3 \\
\hline 15 & $73 / \mathrm{F}$ & II & 1 & 1.0 & 3 \\
\hline 16 & $57 / \mathrm{M}$ & II & 1 & 1.1 & 2 \\
\hline 17 & $57 / \mathrm{M}$ & II & 1 & 1.03 & 3 \\
\hline 18 & $70 / \mathrm{F}$ & II & 1 & 1.22 & 3 \\
\hline 19 & $79 / \mathrm{M}$ & II & 1 & 0.94 & 1 \\
\hline 20 & $59 / \mathrm{M}$ & II & 1 & 1.07 & 2 \\
\hline 21 & $47 / \mathrm{F}$ & II & 1 & 0.98 & 2 \\
\hline 22 & $62 / \mathrm{M}$ & II & 0 & 0.98 & 3 \\
\hline 23 & $50 / \mathrm{M}$ & II & 1 & 1.1 & 2 \\
\hline 24 & $60 / \mathrm{M}$ & II & - & - & 1 \\
\hline 25 & $60 / \mathrm{F}$ & II & 1 & 1.08 & 0 \\
\hline 26 & $53 / \mathrm{M}$ & II & - & - & 1 \\
\hline 27 & $59 / \mathrm{F}$ & II & 1 & 1.05 & 3 \\
\hline 28 & $70 / \mathrm{F}$ & II & 1 & 1.05 & 3 \\
\hline 29 & $66 / \mathrm{M}$ & II & 1 & 1.43 & 3 \\
\hline 30 & $71 / \mathrm{F}$ & II & 2 & 3.4 & 3 \\
\hline 31 & $64 / F$ & III & - & - & 1 \\
\hline 32 & $77 / \mathrm{F}$ & III & 1 & 1.09 & 3 \\
\hline
\end{tabular}

gene amplification, and cases with non-amplification were defined as a ratio of $<2.0$.

\section{Results}

The clinicopathological characteristics, including the patient population, and tumor staging used in this study, are summarized in Table I. The EGFR IHC scores and gene amplification results for 32 PDACs are in Table II. HER-2 gene amplification and IHC scores for 28 PDACs are listed in Table III.

Comparison of EGFR overexpression with amplification in $P D A C$. EGFR overexpression $(\geq 2)$ was seen in 21 of 32 $(65 \%)$ cases. Of the 32 PDACs, $13(41 \%)$ showed $3^{+}$labeling, 
Table II. Clinical characteristrics of cases with EGFR overexpression and amplification.

\begin{tabular}{lccccccc}
\hline & & \multicolumn{3}{c}{ IHC } & & \multicolumn{2}{c}{ FISH } \\
\cline { 3 - 5 } \cline { 6 - 7 } & $\mathrm{n}$ & $3^{+}$ & $2^{+}$ & Negative & $\begin{array}{c}\text { Gene } \\
\text { amplification }\end{array}$ & Negative \\
\hline PDAC & 32 & 13 & 8 & 11 & 0 & 32 \\
& & $41 \%$ & $25 \%$ & $34 \%$ & $0 \%$ & $100 \%$ \\
Stage & & & & & & & \\
I & 9 & 2 & 2 & 5 & 0 & 9 \\
II & 21 & 10 & 6 & 5 & 0 & 21 \\
III & 2 & 1 & 0 & 1 & 0 & 2 \\
\hline
\end{tabular}

Table III. Clinical characteristrics of cases with HER-2 overexpression and amplification.

\begin{tabular}{|c|c|c|c|c|c|c|}
\hline & \multirow[b]{2}{*}{$\mathrm{n}$} & \multicolumn{3}{|c|}{ IHC } & \multicolumn{2}{|l|}{ FISH } \\
\hline & & $3^{+}$ & $2^{+}$ & Negative & $\begin{array}{c}\text { Gene } \\
\text { amplification }\end{array}$ & Negative \\
\hline \multirow[t]{2}{*}{ PDAC } & 28 & 2 & 3 & 23 & 3 & 25 \\
\hline & & $7 \%$ & $10 \%$ & $83 \%$ & $11 \%$ & $89 \%$ \\
\hline \multicolumn{7}{|l|}{ Stage } \\
\hline I & 8 & 0 & 2 & 6 & 0 & 8 \\
\hline II & 19 & 2 & 2 & 15 & 3 & 16 \\
\hline III & 1 & 0 & 0 & 1 & 0 & 1 \\
\hline
\end{tabular}

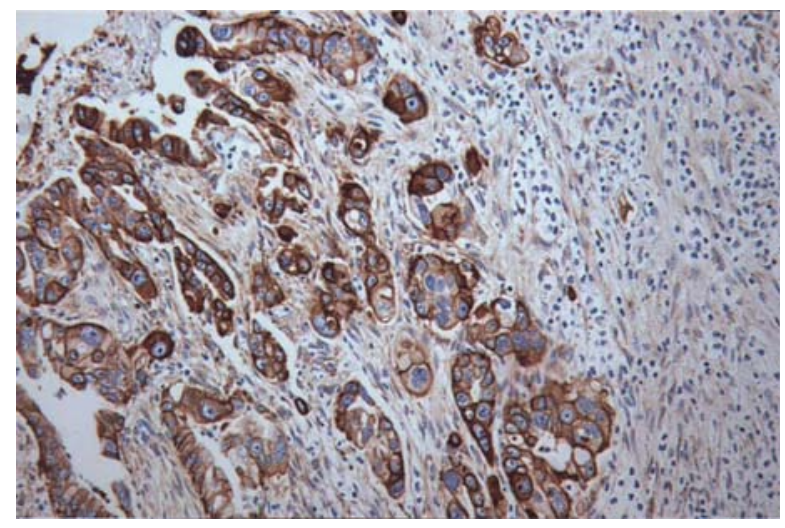

Figure 1. Overexpression of EGFR in PDAC by immunohistochemical stain.

and 8 of $32(25 \%)$ showed $2^{+}$labeling for EGFR by IHC. EGFR overexpression is shown in Fig. 1. Patient age, sex, and tumor stage did not have a significant correlation with EGFR overexpression. EGFR gene amplification was not detected in any of the 32 PDACs by FISH (Fig. 2).

Comparison of HER-2 overexpression with amplification in PDAC. Of the 28 PDAC cases, $2(7 \%)$ showed $3^{+}$labeling, and $3(10 \%)$ showed $2^{+}$labeling for HER-2 by IHC. HER-2

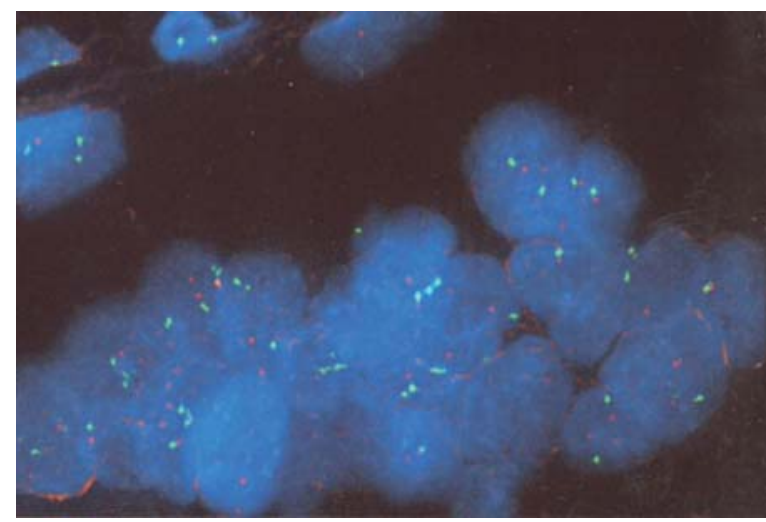

Figure 2. FISH of EGFR in PDAC. No amplification of the EGFR gene was observed.

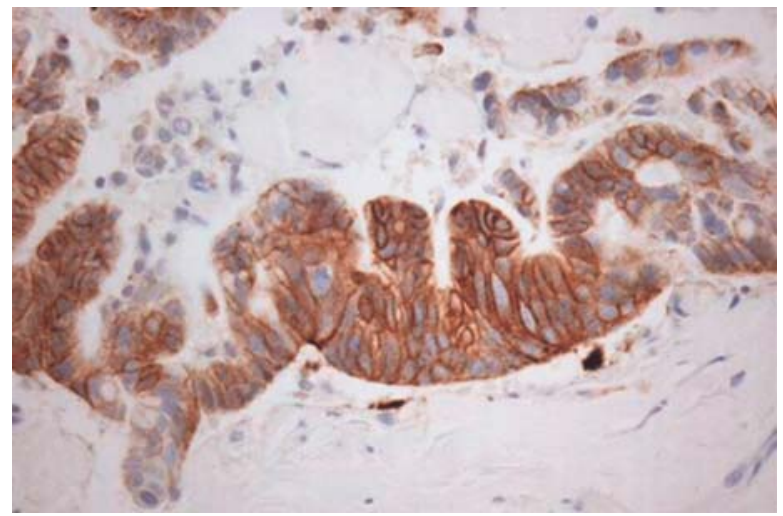

Figure 3. Overexpression of Her-2 in PDAC by immunohistochemical stain.

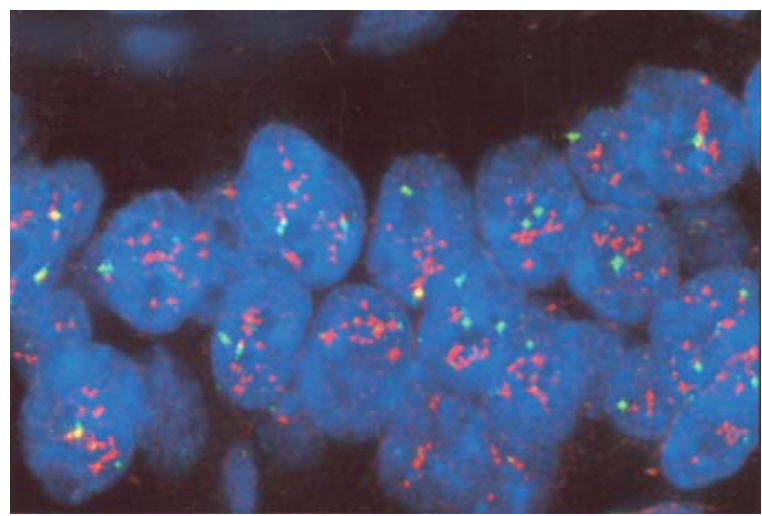

Figure 4. FISH analysis of HER-2 in PDAC demonstrating amplification of HER-2.

overexpression is shown in Fig. 3. HER-2 overexpression also failed to show any correlation with patient age, sex, and tumor stage in our study. HER-2 gene locus was amplified in 3 of 28 PDACs $(11 \%)$. Two of three $(67 \%)$ HER-2 gene amplified cases showed $2^{+}$labeling, and one $(33 \%)$ showed $3^{+}$labeling by HER-2 IHC. HER-2 amplification by FISH is shown in Fig. 4. HER-2 amplification did not have a significant correlation with patient age, sex, and tumor stage. 
Coexpression of EGFR and HER-2 in PDAC. Of the 21 EGFR positive PDAC cases, 5 (24\%) showed positive HER-2 stain by IHC. Of the 21 EGFR positive PDAC cases, 3 (14\%) showed HER-2 gene amplified in FISH studies.

\section{Discussion}

EGFR belongs to a receptor family that has three additional proteins including ErbB-2(HER-2), ErbB-3 and ErbB-4 (11). The EGFR family has a central role in the pathogenesis and progression of variable carcinomas $(12,13)$. The proteins and the growth factors of the EGFR family form a tightly integrated system in which a signal that is received by an individual receptor type is often transmitted to other receptors of the same family (14). This family of receptors is implicated in cell-cell and cell-stromal communication primarily through signal transduction. The epidermal growth factors and their ligands affect the transcription of various genes by phosphorylating or dephosphorylating a series of transmembrane proteins and intracellular signaling intermediates (15). They ultimately affect cell proliferation, survival, motility, and adhesion in various carcinomas including PDAC (16).

Gene amplification, overexpression and activating mutations of EGFR have been reported in various human cancers. In our study, 13 of $32(41 \%)$ cases scored $3^{+}$, and 8 of $32(25 \%)$ cases scored $2^{+}$for EGFR overexpression by IHC. Previous studies have shown that overexpression of EGFR was correlated with shorter postoperative survival in PDAC (17). Gene amplification of EGFR has been demonstrated to occur in different tumor types and is usually associated with EGFR protein overexpression, but overexpression of EGFR in the absence of gene amplification has also been described in various cancers (18). PDAC cases with EGFR overexpression $\left(\geq 2^{+}\right)$labeled by IHC in our study failed to demonstrate gene amplification by FISH. EGFR gene amplification has been reportedly demonstrated in $22-32 \%$ of primary NSCLC, and in $6 \%$ of primary breast carcinomas $(5,19)$. However, there are no previous data for EGFR gene amplification in PDAC.

Mutated forms of EGFR have been studied in NSCLC patients and reported in $\leq 17 \%$ of NSCLC (20). However, only 1 exon 18-21 mutation was seen among 34 lung cancers that could be successfully sequenced. It is still not clear which clinicopathological parameters in NSCLC might be the best predictors of response to EGFR inhibitors and overall survival $(21,22)$. EGFR exon 18-21 mutations have been reported to be ethnically different, being rare in certain populations such as the Middle East or Western country patients with NSCLC (23). The high rate of EGFR gene amplifications could potentially facilitate studies on the predictive role of gene copy number changes for response to anti-EGFR therapies in these patients (23). EGFR exon 19 and 21 mutations have been sought in 40 pancreatic tumors (classification not specified) (7). One recent study reported that no alterations in EGFR exons 18-21 were detected in KRAS-positive or KRAS-negative cases of pancreatic ductal adenocarcinoma (24). Several designed anticancer therapies targeting EGFR receptors are being tested, and available research data suggest some activity of treatment with EGFRTKIs in PDAC, but the experience is limited $(25,26)$.
HER-2/neu, often referred to as C-erbB-2 proto-oncogene mapped to chromosome $17 q 21$, encodes a $185 \mathrm{kDa}$ transmembrane glycoprotein, designated as p185HER2 $(27,28)$. In our study, the positive rate of membranous overexpression of HER-2 protein $\left(>2^{+}\right)$was seen in $17 \%$ of cases by IHC. The reported rates of HER-2 overexpression in PDAC vary between 20 and $80 \%(29,30)$. HER-2 overexpression was found to be a poor prognostic factor in breast carcinoma and PDACs (16). The positive rate of HER-2 gene amplification in our study was seen in $11 \%$ of cases by FISH. Correlation between HER-2 gene amplification by FISH and HER-2 protein overexpression by IHC of the PDAC in our study was 3 of $5(60 \%)$ in IHC positive cases. Overexpression of HER-2 is frequently associated with gene amplification (31). Our results have shown better correlation between HER-2 overexpression by IHC and HER-2 gene amplification by FISH in PDACs than previously reported (29). HER2/neu gene amplification has been reported as a very important prognostic factor for patients with breast cancer since it correlates to the chemotherapy response. However, in PDAC cases, there is controversial data regarding its biological significance.

Tumors that co-express different ErbB receptors are often associated with a more aggressive phenotype and a worse prognosis. Dimerization with other members of the EGFR family is responsible for the formation of active receptors being able to bind a growth factor neuregulin or to be active in signal transduction (32). In our study, five of the 21 (24\%) EGFR positive PDAC cases showed positive HER-2 stain by IHC. Of the 21 EGFR positive PDAC cases, three (14\%) were amplified HER-2 in FISH studies. None of the EGFR negative cases showed HER-2 overexpression or gene amplification. There are reported data establishing a link between expression of EGFR and activation of HER-2 in breast cancer patients (17). Adverse prognostic value of HER-2 overexpression has been observed, especially when HER-2 is in the phosphorylated state or coexpressed with EGFR in invasive breast cancers (17). Some data suggest that HER-2 likely augments EGFR-mediated oncogenicity and addiction to EGFR signaling. One possible reason is the effect that HER-2 has on EGFR cycling. EGFR/HER-2 heterodimers are preferentially recycled back to the plasma membrane compared with EGFR homodimers that are more often targeted for degradation (33). The growth and survival of carcinoma cells appear to be sustained by a network of receptors/ligands of the ErbB family.

This phenomenon has been reported as an important point for therapeutic approaches since the response to anti-EGFR agents might depend on the total level of expression of EGFR receptors and ligands in tumor cells (13). HER-2 has been identified as a potentially important component of the ErbB signaling network in the EGFR TKI-sensitive lung cancers. Substantially, HER-2 amplification, as determined by fluorescence in situ hybridization analysis, was identified as a positive predictor of response to EGFR TKIs (10).

In conclusion, our results show $60 \%$ concurrence between HER-2 protein expression by IHC and HER-2 gene amplification in PDAC. In contrast, no concurrence was demonstrated between EGFR protein overexpression by IHC and EGFR gene amplification. Twenty-one percent of EGFR overexpression cases showed HER-2 co-expression. These 
results suggest that HER-2 appears to be one of the cooperating EGFR family members of the EGFR signal pathway in PDAC. Further studies might be needed for evaluation of co-expression of HER-2 and mutant EGFR in PDAC.

\section{References}

1. Jemal A, Siegel R, Ward E, Murray T, Xu J, Smigal C and Thun MJ: Cancer Statistics, 2006. CA Cancer J Clin 56: 106-130, 2006.

2. Carpelan-Holmstrom M, Nordling S, Pukkala E, Sankila R, Luttges J and Kloppel R: Does anyone survive pancreatic ductal adenocarcinoma? A nationwide study re-evaluating the data of the Finnish Cancer Registry. Gut 54: 385-387, 2005.

3. Lemoine NR, Hughes CM, Barton CM, Poulsom R, Jeffery RE, Kloppel G, Hall PA and Gullick WJ: The epidermal growth factor receptor in human pancreatic cancer. J Pathol 166: 7-12, 1992.

4. Tobita K, Kijima H, Dowaki S, Kashiwagi H, Ohtani Y, Oida Y, Yamazaki H, Nakamura M, Ueyama Y, Tanka M, Inokuchi S and Makuuchi H: Epidermal growth factor receptor expression in human pancreatic cancer: Significance for liver metastasis. Int J Mol Med 11: 305-309, 2003.

5. Hirsch FR, Varella-Garcia M, MaCoy J, West H, Xavier AC, Gumerlock P, Bunn PA, Franklin WA, Crowley J and Gandara DR: Increased epidermal growth factor receptor gene copy detected by fluorescence in situ hybridization associates with increased sensitivity to gefitinib in patients with bronchiolar alveolar carcinoma subtypes: a Southwest Oncology Group Study. J Clin Oncol 23: 6838-6845, 2005.

6. Paez JG, Janne PA, Lee JC, Tracy S, Greulich H, Gabriel S, Herman P, Kaye FJ, Lindeman N, Boggon TJ, Naoki K, Sasaki H, Fujii Y, Eck MJ, Sellers WR, Johnson BE and Meyerson M: EGFR mutations in lung cancer: correlation with clinical response to gefitinib therapy. Science 12: 1490-1500, 2004.

7. Lynch TJ, Bell DW, Sordella R, Gurubhagavatula S, Okimoto RA, Brannigan BW, Harris PL, Haserlat SM, Supko JG, Haluska FG, Louis DN and Harber DA: Activating mutations in the epidermal growth factor receptor underlying responsiveness of non-small cell lung cancer to gefitinib. N Engl J Med 350: 2129-2139, 2004.

8. Engelman JA and Cantley LC: The role of the ErbB family members in non-small cell lung cancers sensitive to epidermal growth factor receptor kinase inhibitors. Clin Cancer Res 12: S4372-S4376, 2006

9. Day JD, Digiuseppe JA, Yeo C, Lai-Goldman M, Anderson SM, Goodman SN, Kern SE and Hruban RH: Immunohistochemical evaluation of HER-2/neu expression in pancreatic adenocarcinoma and pancreatic intraepithelial neoplasms. Hum Pathol 27: 119-124, 1996.

10. Cappuzzo F, Varella-Garcia M, Shigematsu H, Domenichini I, Bartolini S, Ceresoli GL and Hirsh FR: Increased HER2 gene copy number is associated with response to gefitinib therapy in epidermal growth factor receptor positive non-small cell lung cancer patients. J Clin Oncol 23: 5007-5018, 2005.

11. Ferguson KM, Berger MB, Mendrola JM, Cho HS, Leahy DJ and Lemmon MA: EGF activates its receptor by removing interactions that autoinhibit ectodomain dimerization. Mol Cell 11: 507-517, 2003.

12. Salomon DS, Brandt R, Ciardiello F and Normanno N: Epidermal growth factor-related peptides and their receptors in human malignancies. Crit Rev Oncol Hematol 19: 183-232, 1995.

13. Normanno N, Bianco C, De Luca A and Salomon DS: The role of EGF-related peptides in tumor growth. Front Biosci 6: 685-707, 2001.

14. Burgess AW, Cho HS, Eigenbrot C, Ferguson KM, Garrett TP, Leahy DJ, Lemmon MA, Sliwkowski MX, Ward CW and Yokoyama S: An open-and-shut case? Recent insights into the activation of EGF/ErbB receptors. Mol Cell 12: 541-542, 2003.

15. Karunagaran D, Tzahar E, Beerli RR, Chen X, Hynes NE, Graus-Porta D, Ratzkin BJ, Seger R, Hynes NE and Yarden Y: ErbB-2 is a common auxiliary subunit of NDF and EGF receptors: implications for breast cancer. EMBO J 15: 254-264, 1996.

16. Ross JS and Fletcher JA: The HER-2/neu Oncogene in breast cancer: prognostic factor, predictive factor, and target for therapy. Oncologist 3: 237-252, 1998.
17. Di Giovanna MP, Stern DF, Edgerton SM, Whalen SG, Moore D and Thor AD: Relationship of epidermal growth factor receptor expression to ErbB-2 signaling activity and prognosis in breast cancer patients. J Clin Oncol 23: 1152-1160, 2005

18. Normanno N, De Luca A, Bianco C, Strizzi C, Mancino M, Maiello MR, Carotenuto A, De Feo G, Caponigro F and Salmon DS: Epidermal growth factor receptor (EGFR) signaling in cancer. Gene 366: 2-16, 2006.

19. Bhargava R, Gerald WL, Li AR, Pan Q, Lal P, Ladanyi M and Chen B: EGFR gene amplification in breast cancer: correlation with epidermal growth factor receptor mRNA and protein expression and Her2 status and absence of EGFR-activating mutations. Mod Pathol 18: 1027-1033, 2005.

20. Marchetti A, Martella C, Felicioni L, Barassi F, Salvatore S, Chella A, Camplese PP, Iarussi T, Mucilli F, Mezzetti A, Cuccurullo F, Sacco R and Buttitta F: EGFR mutations in non-small cell lung cancer: analysis of a large series of cases and development of a rapid sensitive method for diagnostic screening with potential implications on pharmacologic treatment. J Clin Oncol 23: 857-865, 2005.

21. Willmore-Payne C, Holden JA and Layfield LJ: Detection of epidermal growth factor receptor and human epidermal growth factor receptor 2 activating correlation with gene copy number, protein expression, and hormone receptor expression. Hum Pathol 37: 755-763, 2006.

22. Johnson BE and Janne PA: Selecting patients for epidermal growth factor receptor inhibitor treatment: A FISH story or a table of mutations. J Clin Oncol 23: 6813-6816, 2005.

23. Al-Kuraya K, Sirj AK, Bavi P, Al-Jommah N, Ezzat A, Sheikh S, Amr S, Al-Dayel F, Simon R and Guido S: High epidermal growth factor receptor amplification rate but low mutation frequency in Middle East lung cancer population. Hum Pathol 37: 453-457, 2006.

24. Immervoll H, Hoem D, Kugarajh K, Steine SJ and Molven A: Molecular analysis of the EGFR-RAS-RAF pathway in pancreatic ductal adenocarcinomas: lack of mutations in the BRAF and EGFR genes. Virchows Arch 448: 788-796, 2006.

25 Blaszkowsky LS, Kulke KH and Ryan DP: A phase II study of erlotinib in combination with capecitabine in previously treated patients with metastatic pancreatic cancer. Proc Am Soc Clin Oncol 23 (Suppl 16): 4099a, 2005.

26. Moore MJ, Goldstein D and Hamm J: Erlotinib plus gemcitabine compared to gemcitabine alone in patients with advanced pancreatic cancer. A phase III trial of the National Cancer Institute of Canada Clinical Trials Group (NCIC-CTG). Proc Am Soc Clin Oncol 239 (Suppl 16): 1a, 2005.

27. Akiyama T, Sudo C, Ogawara H, Toyoshima $\mathrm{H}$ and Yamamoto T: The product of the human c-erbB-2 gene: a 185-kilodalton glycoprotein with tyrosin kinase activity. Science 232: 1644-1646, 1986.

28. Bargmann CI, Hung MC and Weinberg RA: The neu oncogene encodes an epidermal growth factor receptor-related protein. Nature 319: 226-230, 1986.

29. Safran H, Stainhoff H, Mangray S, Rathore R, King TC, Chai L, Berzein K, Moore T, Iannitti D, Reiss P, Pasquariello T, Akerman P, Quirk D, Mass R, Goldstein L and Tantravahi U: Overexpression of the HER-2/neu oncogene in pancreatic adenocarcinoma. Am J Clin Oncol 24: 496-499, 2001.

30. Saxby AJ, Nielsen A, Scarlett CJ, Clarkson A, Morey A, Gill A and Smoth RC: Assessment of HER-2 status in pancreatic adenocarcinoma: correlation of immunohistochemistry, quantitative real-time RT-PCR, and FISH with aneuploidy and survival. Am J Surg Pathol 29: 1125-1134, 2005.

31. Shigematsu H, Takahashi T, Nomura M, Majmudar K, Suzuki M, Lee H, Wistuba II, Fong KM, Toyooka S, Shimizu N, Fujisawa T, Minna JD and Gazdar AF: Somatic mutations of the HER2 kinase domain in lung adenocarcinoma. Cancer Res 65: 1642-1646, 2005.

32. Pinkas-Kramarski R, Shelly M, Guarino BC, Wang LM, Lyass L, Alroy I, Alimandi M, Kuo A, Moyer JD, Lavi S, Eisenstein M, Ratzkin BJ, Seger R, Bacus SS, Pierce JH, Andrews GC and Yarden Y: ErbB tyrosine kinases and the two neuregulin families constitute a ligand-receptor network. Mol Cell Biol 18: 6090-6101, 1998

33. Mosesson Y and Yarden Y: Oncogenic growth factor receptors: implications for signal transduction therapy. Semin Cancer Biol 14: 262-270, 2004. 